\author{
Edyta BĄKOWSKA \\ Mgr, Instytut Geografii Społeczno-Ekonomicznej Gospodarki Przestrzennej, Uniwersytet im. Adama Mickiewicza w Poznaniu \\ edyta.bakowska@amu.edu.pl
}

\title{
ZMIANY DEMOGRAFICZNE JAKO WYZWANIE DLA POLITYK LOKALNYCH PRZYKŁAD ROKIETNICY W AGLOMERACJI POZNAŃSKIEJ
}

\begin{abstract}
Abstrakt: Aglomeracja poznańska stanowi jeden z najszybciej rozwijających się obszarów podmiejskich w Polsce. Intensywne procesy migracyjne na tym obszarze spowodowały w latach 2002-2015 wzrost liczby mieszkańców o 35,9\%, wpływając na konieczność sprostania przez władze lokalne nowym wyzwaniom związanym ze zmianami demograficznymi oraz przestrzennymi. Celem autorki artykułu jest identyfikacja procesów zachodzących w podpoznańskiej gminie Rokietnica, w której pomimo znaczącego przyrostu ludności udało się w ostatnich latach podjąć kroki przeciwdziałające negatywnym skutkom intensywnej suburbanizacji.
\end{abstract}

Słowa kluczowe: aglomeracja poznańska, suburbanizacja, strefa podmiejska, migracje, zmiany demograficzne, polityka lokalna.

\section{DEMOGRAPHIC CHANGES AS A CHALLENGE FOR LOCAL POLICY. EXAMPLE OF ROKIETNICA IN THE POZNAŃ AGGLOMERATION}

\begin{abstract}
The Poznań agglomeration is one of the most interesting case studies of the development of suburban areas in Poland. As a result of intensive migrations to the Poznań suburban zone (growth of 35,9\% of inhabitants in years 2002-2015), communes are obliged to face the needs of growing population which age structure is dominated mostly by young people. The processes of socio-demographic and spatial changes affect on the need for forward-looking analysis of the challenges and needs of the transformed population in the areas of urban planning, services, infrastructure and intercommunal cooperation. The purpose of this article was to identify the challenges associated with the suburbanization at Rokietnica - one of the fastest growing communes in the Poznań agglomeration, where local authorities take various steps to face the negative effects of the Poznań suburban zone dynamic development.

Keywords: Poznań agglomeration, suburbanisation, suburban zone, migrations, demographic changes, local policy.
\end{abstract}

\section{WSTĘP}

Suburbanizacja jest procesem, który po 1989 r. nabrał w Polsce szczególnego tempa i przyczynił się do kształtowania struktur przestrzenno-funkcjonalnych aglomeracji, w tym także obszaru aglomeracji poznańskiej (Parysek, Wojtasiewicz, Gruchman 2010, s. 21). Procesy społeczno-demograficzne i przestrzenne, zachodzące w wyniku urbanizacji stref podmiejskich aglomeracji, wpływają na konieczność dokonywania przez przedstawicieli samorządów lokalnych świadomej i perspektywicznej analizy zachodzących zmian.

W aglomeracji poznańskiej jednym z ciekawszych przypadków jest gmina Rokietnica, położona na obszarze najintensywniejszych w Polsce procesów suburbanizacji. Procesy te przejawiają się zmianami demograficznymi związanymi $\mathrm{z}$ intensywnymi migracjami i zmianą struktury demograficznej mieszkańców wpły- wającymi na ponadprzeciętny poziom urbanizacji, określany na podstawie wartości syntetycznego wskaźnika Perkala (Kaczmarek 2014, s. 40-41). W okresie 2002-2015 r. przyrost liczby mieszkańców gminy wyniósł $81 \%$, przy saldzie migracji na średnim poziomie 550 osób rocznie. Wpłynęło to w istotny sposób na perspektywy rozwoju gminy oraz wyzwania władz samorządowych w kontekście zaspokajania potrzeb szybko rosnącej liczby mieszkańców o specyficznej strukturze wiekowej, w której dominują ludzie młodzi.

Celem autorki niniejszego artykułu była identyfikacja wyzwań związanych z procesem suburbanizacji w gminie Rokietnica oraz działań władz lokalnych w kierunku przeciwdziałania negatywnym skutkom tak dynamicznego rozwoju tej części strefy podmiejskiej Poznania. 


\section{WYZWANIA ZWIAZZANE Z PROCESEM SUBURBANIZACJI W POLSCE}

Obserwowany w ostatnich latach proces intensywnych migracji wymaga od władz samorządowych stref podmiejskich identyfikacji spodziewanych kierunków zmian i związanych z nimi wyzwań w zakresie lokalnej polityki rozwoju. Do trudności obserwowanych w strefach podmiejskich związanych z rozprzestrzenianiem się zabudowy mieszkaniowej przyczynia się brak koordynacji polityki przestrzennej w obrębie wielkich miast i na obszarach metropolitalnych (Lorens 2005). Sprzyja to możliwości swobodnego zaspokajania potrzeb mieszkaniowych, przy dominujących preferencjach dla „domu z ogrodem”, oraz dążeniu deweloperów i inwestorów do zagospodarowania terenów najłatwiej dostępnych ze względu na ich jakość i cenę. Tę listę można uzupełnić także o inne czynniki społeczno-ekonomiczne, takie jak: wzrost realnych dochodów ludności, zmniejszenie kosztów dojazdów do pracy, czy też kryzysowe zjawiska w centralnych częściach miast (Słodczyk 2003). Niemniej jednak to dążenie do polepszenia warunków mieszkaniowych jest jednym z najważniejszych powodów przeprowadzki z miasta do strefy podmiejskiej, co zdaniem K. Kajdanek (2012) jest efektem przeszłych doświadczeń mieszkaniowych i kalkulacji ekonomicznej.

Suburbanizacja wynikająca ze wspomnianych wcześniej czynników cechuje się w Polsce brakami w zarządzaniu i polityce przestrzennej samorządów terytorialnych (Lorens 2005). Konsekwencją jest chaos przestrzenny widoczny m.in. poprzez przeznaczanie znacznych powierzchni gruntów pod zabudowę, co wywołuje tzw. boom migracyjny, za którym z kolei nie nadąża rozwój lokalnych usług. Tym samym nowi mieszkańcy nie mogą $\mathrm{w}$ pełni zaspokajać swoich potrzeb związanych z edukacją, opieką zdrowotną, kulturą, rekreacją. Są więc oni nadal silnie związani z miastem i miejscami, do których uczęszczali przed wyprowadzką (Kajdanek 2012). Niekontrolowany rozwój zabudowy wpływa także na inne czynniki utrudniające asymilację nowych mieszkańców z nowym miejscem zamieszkania. Należy do nich także niedobór atrakcyjnych przestrzeni sąsiedzkich, których obecność może być kluczowa dla kreowania kontaktów sąsiedzkich (Chmielewski 2001). Istotną konsekwencją ułomnej polityki przestrzennej samorządów terytorialnych zmagających się z suburbanizacją strefy podmiejskiej jest słabość wyposażenia infrastrukturalnego nowo zabu- dowywanych terenów, tj. dysproporcje między rozwojem zabudowy mieszkaniowej a infrastrukturą techniczną oraz trudności komunikacyjne wpływające na uzależnienie mieszkańców od samochodu powiększające natężenie ruchu drogowego. Niekontrolowany i żywiołowy dalszy rozwój zabudowy podnosi koszty budowy sieci infrastruktury komunalnej i jej utrzymania. $\mathrm{Z}$ perspektywy mieszkańców braki infrastrukturalne obniżają ich jakość życia, co wynika m.in. z braku poczucia bezpieczeństwa związanego z brakiem oświetlenia na osiedlu, czy też uciążliwości związanych z codziennymi przejazdami po nieutwardzonych drogach.

\section{ROZWÓJ STREFY PODMIEJSKIEJ POZNANIA}

Strefa podmiejska Poznania jest szczególnym przykładem obszaru silnej suburbanizacji, o dużym potencjale w skali kraju (Kaczmarek i in. 2014). W całym powiecie poznańskim, w którego skład wchodzi 17 gmin, średni przyrost liczby ludności w latach 2002-2015 wyniósł 35,9\%, jednak w trzech gminach przekroczył $90 \%$. Jak przedstawia tab. 1, były to gminy wiejskie graniczące z Poznaniem od zachodu (rys. 1): Dopiewo (107,5\%), Komorniki $(105,1 \%)$ oraz Rokietnica $(94,9 \%)$. Łącznie w powiecie poznańskim w latach 2002-2015 przybyło 96657 mieszkańców, osiągając w 2015 r. poziom 366037 osób w stosunku do 269380 w 2002 r. Jedynym miastem w aglomeracji poznańskiej ${ }^{1}$, które zanotowało spadek liczby mieszkańców - był Poznań, którego liczba ludności spadła w tych 13 latach o 6,0\%.

Zmiany liczby ludności w aglomeracji poznańskiej wyraźnie przekładają się na przyrost zasobów mieszkaniowych stanowiąc bardzo istotny przejaw procesu suburbanizacji tego obszaru. W strefie podmiejskiej miasta Poznania średni przyrost mieszkań w latach 2005-2014 wyniósł 38,0\% (tab. 2, rys. 2). Podobnie jak w przypadku zmian liczby ludności, najwyższy przyrost odnotowano w Komornikach (117,6\%), Dopiewie $(98,2 \%)$ i Rokietnicy $(85,4 \%)$. Łącznie w powiecie poznańskim w latach 2005-2014 przybyło ich 32361 , osiągając w 2014 r. poziom 117550 osób w stosunku do 85189 w 2005 r. Poznań, obok Puszczykowa i gminy Buk, zanotował najniższy przyrost liczby nowych mieszkań, który wyniósł 11,8\%, zwiększając w badanym dziesięcioleciu liczbę mieszkań o 26052, co nie przełożyło się jednak na wzrost liczby mieszkańców. 
Tab. 1. Zmiany liczby ludności w aglomeracji poznańskiej w latach 2002-2015

\begin{tabular}{|c|c|c|c|c|c|}
\hline \multirow{2}{*}{ Lp. } & \multirow{2}{*}{$\begin{array}{l}\text { Jednostka } \\
\text { terytorialna }\end{array}$} & \multicolumn{2}{|c|}{ Liczba ludności } & \multirow{2}{*}{$\begin{array}{c}\text { Gęstość zaludnienia } \\
\text { w osobach } / \mathrm{km}^{2} \\
\text { w } 2015 \mathrm{r} \text {. }\end{array}$} & \multirow{2}{*}{$\begin{array}{l}\text { Zmiana liczby ludności } \\
\text { (w \%), w l. 2002-2015 }\end{array}$} \\
\hline & & 2002 r. & 2015 r. & & \\
\hline 1 & Dopiewo & 11302 & 23453 & 217 & 107,5 \\
\hline 2 & Komorniki & 12471 & 25572 & 385 & 105,1 \\
\hline 3 & Rokietnica & 8045 & 15679 & 198 & 94,9 \\
\hline 4 & Kórnik & 15625 & 24774 & 133 & 58,6 \\
\hline 5 & Suchy Las & 11155 & 16510 & 142 & 48,0 \\
\hline 6 & Tarnowo Podgórne & 16794 & 24694 & 243 & 47,0 \\
\hline 7 & Kleszczewo & 5017 & 7500 & 101 & 49,5 \\
\hline 8 & Mosina & 24042 & 31088 & 181 & 29,3 \\
\hline 9 & Swarzędz & 37658 & 47947 & 471 & 27,3 \\
\hline 10 & Luboń & 24934 & 31067 & 2300 & 24,6 \\
\hline 11 & Pobiedziska & 15427 & 19106 & 101 & 23,9 \\
\hline 12 & Czerwonak & 22115 & 27094 & 328 & 22,5 \\
\hline 13 & Kostrzyn & 15159 & 17741 & 115 & 17,0 \\
\hline 14 & Stęszew & 13559 & 14910 & 85 & 10,0 \\
\hline 15 & Murowana Goślina & 15273 & 16760 & 97 & 9,7 \\
\hline 16 & Puszczykowo & 9036 & 9753 & 595 & 7,9 \\
\hline 17 & Buk & 11768 & 12389 & 137 & 5,3 \\
\hline 18 & Poznań & 577117 & 542348 & 2071 & $-6,0$ \\
\hline
\end{tabular}

Źródło: Bank Danych Lokalnych GUS.

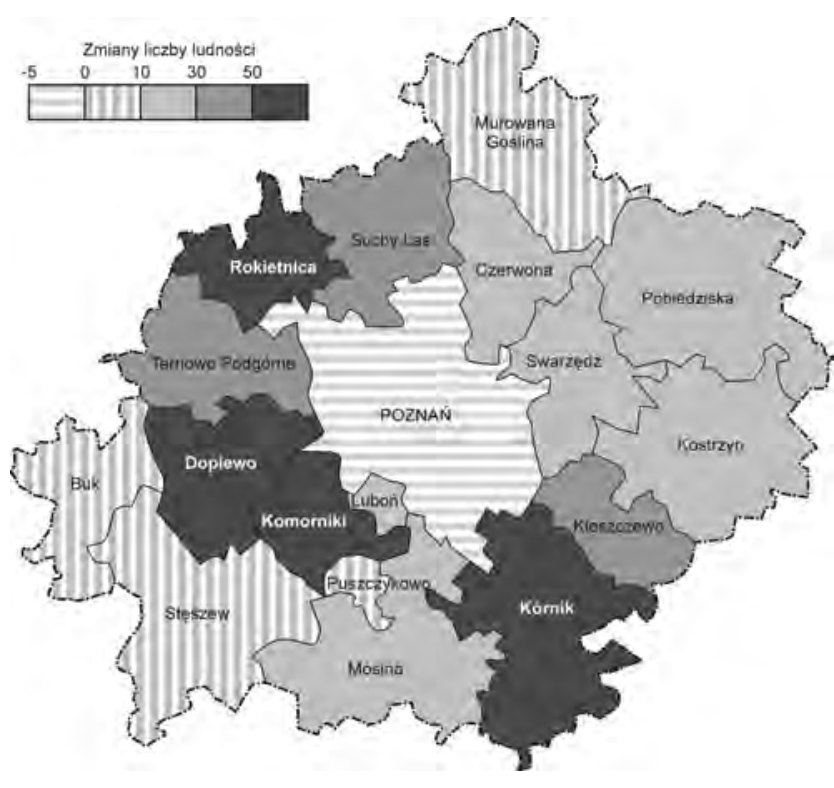

Rys. 1. Zmiany liczby ludności w aglomeracji poznańskiej w latach 2002-2015

Źródło: opracowanie własne na podstawie danych BDL GUS
Tab. 2. Zasoby mieszkaniowe w aglomeracji poznańskiej w latach 2005-2014

\begin{tabular}{|c|l|r|r|c|}
\hline \multirow{2}{*}{ Lp. } & \multirow{2}{*}{$\begin{array}{c}\text { Jednostka } \\
\text { terytorialna }\end{array}$} & \multicolumn{3}{|c|}{ Zasoby mieszkaniowe ogółem } \\
\cline { 3 - 5 } & & 2005 & 2014 & $\begin{array}{c}\text { Przyrost w \% } \\
\text { w l. 2005-2014 }\end{array}$ \\
\hline 1 & Komorniki & 3945 & 8585 & 117,6 \\
\hline 2 & Dopiewo & 3795 & 7520 & 98,2 \\
\hline 3 & Rokietnica & 2650 & 4914 & 85,4 \\
\hline 4 & Kleszczewo & 1468 & 2390 & 62,8 \\
\hline 5 & Kórnik & 5048 & 8119 & 60,8 \\
\hline 6 & Mosina & 6801 & 9513 & 39,9 \\
\hline 7 & Tarnowo Podgórne & 5350 & 7465 & 39,5 \\
\hline 8 & Suchy Las & 4184 & 5563 & 33,0 \\
\hline 9 & Pobiedziska & 4797 & 6286 & 31,0 \\
\hline 10 & Swarzędz & 12584 & 16130 & 28,2 \\
\hline 11 & Luboń & 8917 & 11263 & 26,3 \\
\hline 12 & Stęszew & 3767 & 4539 & 20,5 \\
\hline 13 & Kostrzyn & 4249 & 4963 & 16,8 \\
\hline 14 & Czerwonak & 7121 & 8261 & 16,0 \\
\hline 15 & Murowana Goślina & 4474 & 5172 & 15,6 \\
\hline 16 & Buk & 3215 & 3663 & 13,9 \\
\hline 17 & Puszczykowo & 2824 & 3204 & 13,5 \\
\hline 18 & Poznań & 221689 & 247741 & 11,8 \\
\hline
\end{tabular}

Źródło: Bank Danych Lokalnych GUS. 


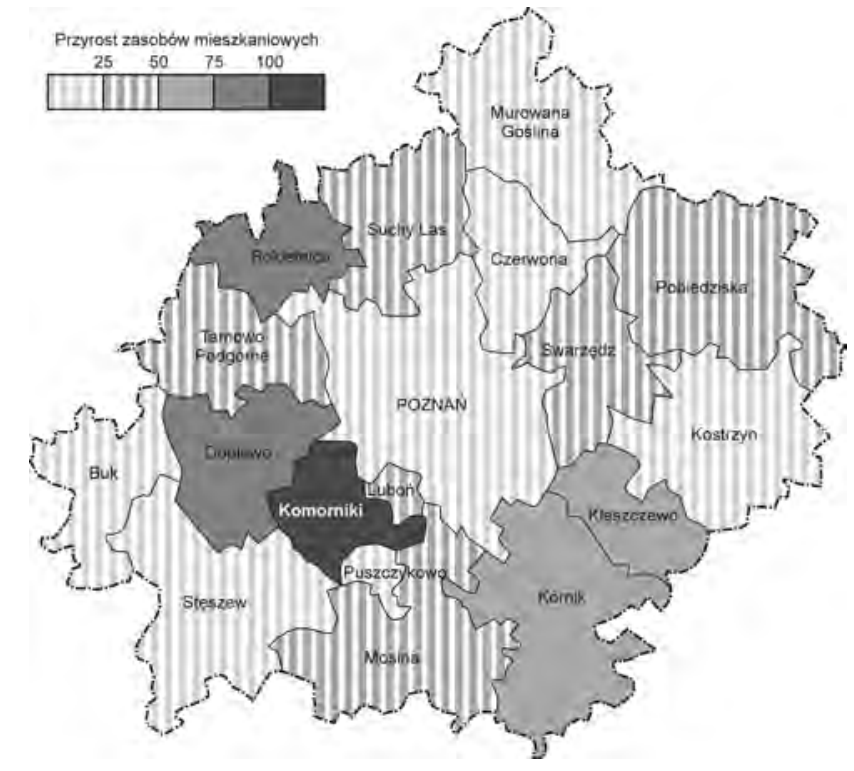

Rys. 2. Zasoby mieszkaniowe w aglomeracji poznańskiej w latach 2005-2014

Źródło: opracowanie własne na podstawie danych BDL GUS

\section{SUBURBANIZACJA W GMINIE ROKIETNICA}

Gmina Rokietnica należy do najsilniej doświadczających suburbanizacji terenów aglomeracji poznańskiej. Według Głównego Urzędu Statystycznego, w 2015 r. liczba ludności gminy wynosiła 15679 osób (wg faktycznego miejsca zamieszkania). W porównaniu do roku 2002 liczba ta niemalże podwoiła się i wzrosła o 7634 osób, czyli o 94,9\%. W latach 2002-2015 gmina Rokietnica charakteryzowała się wysokim przyrostem liczby ludności (rys. 3 i 4), zwiększając corocznie liczbę mieszkańców średnio o 550 osób. Wzrost liczby mieszkańców był wynikiem nie tyle przyrostu naturalnego (rys. 3), ile bardzo wysokiego salda migracji (rys. 4), które w latach 2005-2014 wyniosło łącznie 5301 osób. W całym analizowanym okresie napływ kobiet przewyższał nieznacznie napływ mężczyzn (współczynnik feminizacji migrantów wyniósł 113), co jest charakterystyczne dla obszarów dużych aglomeracji miejskich. Odpływ mieszkańców z gminy Rokietnica w ostatnich 10 latach wyniósł tylko tysiąc osób, więc był 6-krotnie mniejszy od napływu.

Wzrostowi zaludnienia sprzyjał rozwój budownictwa mieszkaniowego w gminie Rokietnica. Niewątpliwie dominującym kierunkiem migracji do gminy były przemieszczenia ludności z miasta Poznania typowe dla zjawiska suburbanizacji. Spośród 6297 osób, które według danych ewidencyjnych Urzędu Gminy Rokiet- nica, zameldowały się w latach 2004-2013 w gminie, 4054 (64\%) pochodziły z Poznania. Blisko 800 imigrantów (13\%) przybyło do gminy Rokietnica $\mathrm{z}$ innych, na ogół pobliskich gmin powiatów poznańskiego i szamotulskiego. Znaczny odsetek (kolejne 13\%) migrantów stanowili dawni mieszkańcy powiatów ościennych, głównie szamotulskiego, obornickiego i wągrowieckiego. Wśród osiedlających się $\mathrm{w}$ gminie były także osoby pochodzące z pozostałych terenów Wielkopolski, głównie ze średnich jej miast, takich jak: Konin, Kalisz, Leszno i Gniezno, oraz dużych miast Polski - Warszawa, Łódź i Szczecin.

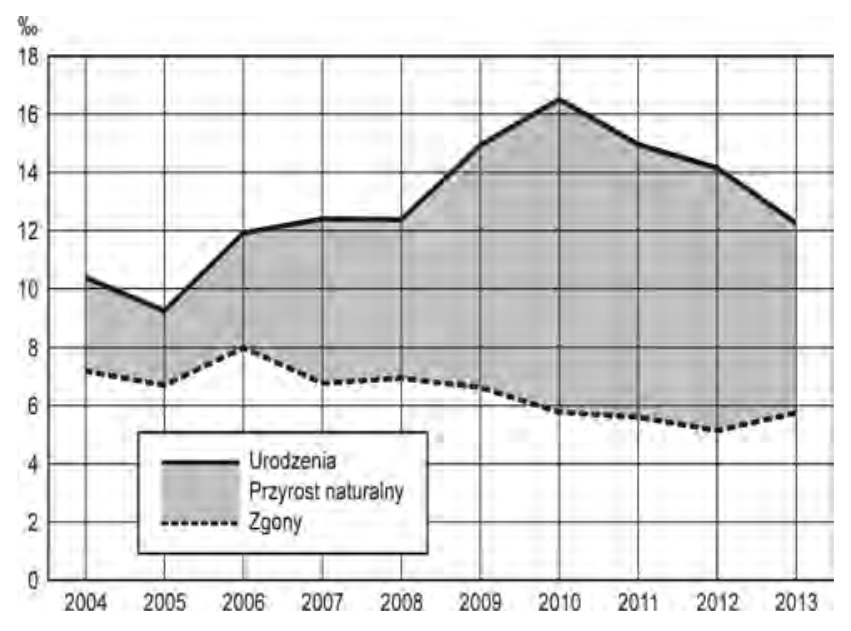

Rys. 3. Przyrost naturalny w gminie Rokietnica w latach 2004-2013 Źródło: opracowanie własne na podstawie danych ewidencyjnych Urzędu Gminy w Rokietnicy

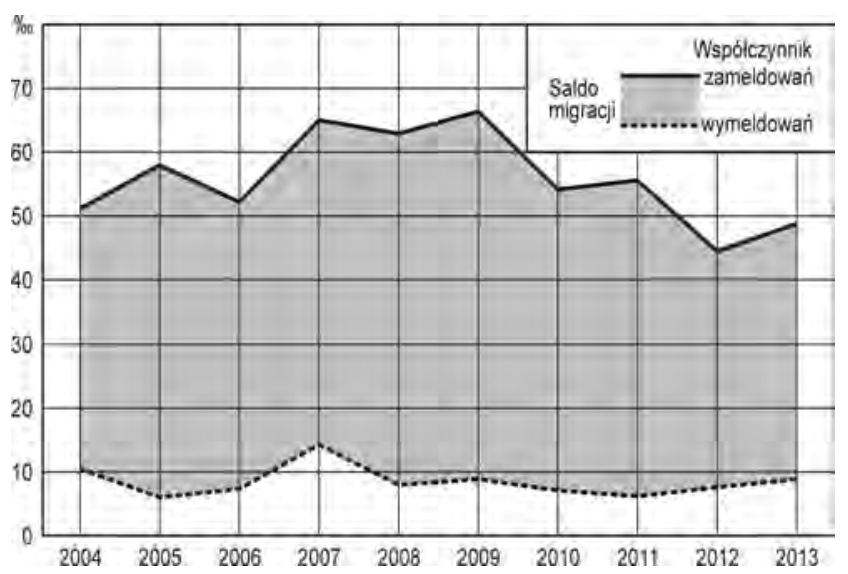

Rys. 4. Saldo migracji w gminie Rokietnica w latach 2004-2013 Źródło: opracowanie własne na podstawie danych ewidencyjnych Urzędu Gminy w Rokietnicy

W wyniku procesów suburbanizacji w gminie Rokietnica widoczna jest zależność między presją inwestycyjną na danym obszarze a spadkiem spójności tkanki urbanistycznej. Według „Studium uwarunko- 
wań i kierunków zagospodarowania przestrzennego gminy Rokietnica” (2016), jej część północną cechują mniejsze zakłócenia struktur przestrzennych jednostek osadniczych, niż część południową (z wyjątkiem Cerekwicy, gdzie rozwiązania przestrzenne były szczególnie nietrafne i dewastujące środowisko). Budownictwo indywidualne (niedeweloperskie) wykazuje najczęściej nadmierne i nieuzasadnione zróżnicowanie pod względem funkcji, formy i barwy. Nowe inwestycje z kolei nie harmonizują z parametrami otoczenia. Podobnie jak w całej aglomeracji poznańskiej, także i w gminie Rokietnica intensywna presja inwestycyjna powoduje wyłączanie z użytkowania rolniczego kolejnych terenów (Parysek, Wojtasiewicz, Gruchman 2010).

\section{PRZEWIDYWANE KIERUNKI ROZWOJU GMINY ROKIETNICA}

Zgodnie z prognozą demograficzną, sporządzoną na potrzeby polityki oświatowej w gminie Rokietnica (Kaczmarek, Bąkowska 2015), uwzględniającą aktualne trendy migracyjne w gminie, w 2030 r. szacowana liczba mieszkańców wyniesie tu 24836 osób, co daje wzrost o dalsze 60,9\% w stosunku do stanu z 2015 r. Według maksymalnego wariantu tej prognozy, w perspektywie najbliższych 15 lat eksplozywny wręcz przyrost liczby ludności gminy będzie trwać. Populacja gminy zwiększy się w każdej grupie wiekowej, a szczególnie w grupach 10-19 lat (dzieci obecnie napływających do gminy mieszkańców) oraz 40-59 lat (starzejąca się grupa osób przybyłych tu w ostatniej dekadzie).

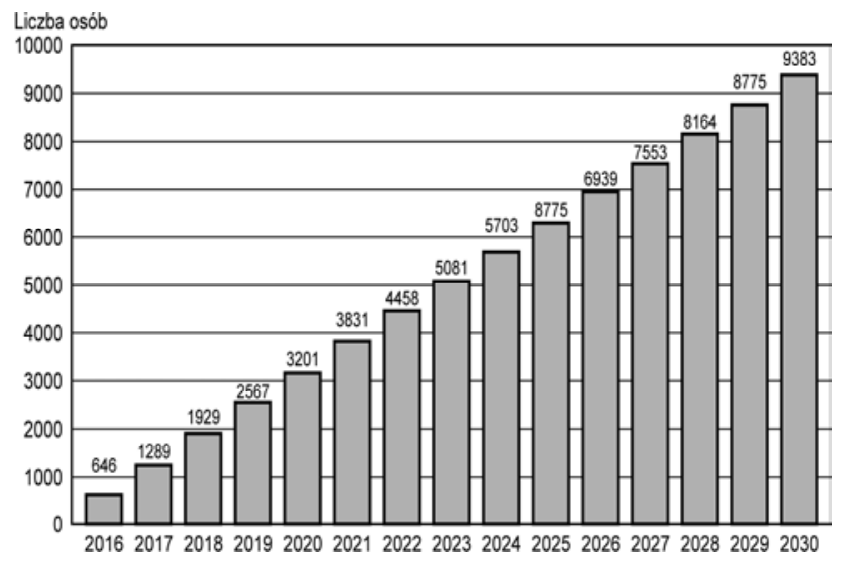

Rys. 5. Prognozowane przyrosty liczby ludności w gminie Rokietnica w latach 2016-2030

Źródło: T. Kaczmarek, E. Bąkowska (2015)
Wyniki cytowanej tu prognozy demograficznej wskazują, że liczne dziś pokolenie dzieci urodzonych w latach 2005-2015 w perspektywie najbliższych 10 20 lat wejdzie w wiek edukacji szkolnictwa wyższego oraz w wiek wczesnoprodukcyjny. Pokolenie to po 2030 r. będzie zakładało rodziny, co może oznaczać ponowny przyrost liczby urodzeń w gminie i kolejny wzrost jej zaludnienia. Liczne pokolenie powojennego wyżu demograficznego (z lat 50. XX w.) osiągnie wiek 70-80 lat, natomiast pokolenie wyżu (z lat 80.) - 40-50 lat. Prognoza ta wskazuje, że w gminie Rokietnica systematycznie będzie zwiększać się liczba osób dożywających późnej starości.

\section{WYZWANIA I PRZYJĘTE ROZWIAZANIA}

Zgodnie ze „Studium uwarunkowań i kierunków rozwoju gminy Rokietnica" (2016) dalszy rozwój gminy musi być związany z zapewnieniem zasobów mieszkaniowych odpowiednich do potencjalnego wzrostu liczby jej mieszkańców, a także $\mathrm{z}$ wdrożeniem działań, które zmierzać powinny do intensywnego wykorzystania jej terenów. Tym samym dokumentom planistycznym w gminie przyświeca tzw. idea konsolidacji przestrzennej i kształtowania centrum, która wskazuje m.in. na wprowadzenie na centralnym terenie intensywnej centrotwórczej zabudowy, wykorzystanie obecnych i wyznaczonych terenów pod zabudowę oraz zapewnienie poprawy walorów przestrzennych przez akumulację i racjonalizację wykorzystania dostępnych obszarów w ramach rdzenia osadniczego. $\mathrm{W}$ tym celu w listopadzie 2015 r. władze gminy przystąpiły do opracowania projektów miejscowych planów zagospodarowania przestrzennego dla obszaru pozostawionego przez spółdzielnię rolno-spożywczą funkcjonującą kiedyś $\mathrm{w}$ centrum wsi. Zgodnie z założeniami tego projektu, teren ma stać się nowym centrum miejscowości charakteryzującym się najwyższą w całej gminie gęstością zabudowy, obecnością funkcji usługowych i handlowych oraz atrakcyjnymi przestrzeniami publicznymi, w tym rynku lub placu. Planowanie przestrzenne w gminie oparte jest także na współpracy międzysamorządowej wynikającej z członkostwa gminy Rokietnica w Stowarzyszeniu „Metropolia Poznań”, na którego zlecenie w 2015 r. opracowana została koncepcja kierunków rozwoju przestrzennego metropolii Poznań.

W wyniku szybkiego przyrostu liczby mieszkańców na potrzeby gminy opracowana została cytowana 
wcześniej prognoza demograficzna, służąca określeniu przyszłego zapotrzebowania mieszkańców na usługi oświatowe. Opracowanie to, z perspektywą do 2030 r., określa potrzebę budowy nowych placówek, zarówno szkoły podstawowej, jak i gimnazjum. Według tej prognozy $\mathrm{w}$ perspektywie najbliższych pięciu lat zapotrzebowanie na miejsca w szkole podstawowej zwiększy się o 1000, a w gimnazjach o 600 (Kaczmarek, Bąkowska 2015, s. 64-65). Tym samym prace nad budową nowych obiektów szkolnych są zadaniem priorytetowym władz gminy.

Wśród realizowanych inwestycji są także i te na rzecz gospodarki komunalnej i infrastruktury technicznej. W roku 2015 otwarto w Rokietnicy nową oczyszczalnię ścieków, a w ramach partnerstwa gmin aglomeracji poznańskiej w najbliższych latach będzie realizowany projekt Poznańskiej Kolei Metropolitalnej. Projekt ten ma na celu poprawę infrastruktury kolejowej i zwiększenie częstotliwości kursowania pociągów, a także określenie mechanizmów efektywnej współpracy samorządów różnych szczebli, będącej podstawą do funkcjonowania połączeń tej kolei („Master plan dla Poznańskiej Kolei Metropolitalnej”).

Władze gminy są otwarte na współpracę z mieszkańcami w zakresie podejmowania decyzji. W tym celu podjęto Uchwałę Rady Gminy Rokietnica z 26 września 2011 r. w sprawie wprowadzenia Regulaminu Konsultacji Społecznych. Jej celem było stworzenie podstaw do przeprowadzania miarodajnych i transparentnych konsultacji społecznych, pobudzenie aktywności lokalnej mieszkańców Rokietnicy, poznanie opinii mieszkańców w celu trafnego reprezentowania ich wspólnego dobra, wprowadzenie konsultacji jako stałego elementu podejmowania decyzji w sprawie gminy, a także tworzenie więzi społecznych i tożsamości lokalnej. Jednym z przykładów szeroko konsultowanych problemów w gminie było wspomniane już opracowanie projektów miejscowych planów zagospodarowania przestrzennego centrum Rokietnicy. Ten nieużytkowany od wielu lat teren ma ogromny potencjał stworzenia we wsi przestrzeni o charakterze mieszkalno-usługowym, wraz $\mathrm{z}$ atrakcyjnymi przestrzeniami publicznymi służącymi wykreowaniu nowego centrum miejscowości. Badania preferencji mieszkańców odnośnie do tego obszaru przeprowadzono z wykorzystaniem nowych metod konsultacji społecznych, tzw. geoankiet, opierających się na Partycypacyjnych Systemach Informacji Geograficznej (PPGIS) (Kaczmarek, Bąkowska 2016).

\section{WNIOSKI}

Samorządy lokalne, funkcjonujące w strefie silnej suburbanizacji, borykają się z wieloma wyzwaniami będącymi efektem dynamicznego przyrostu liczby nowych mieszkańców generujących potrzeby w zakresie m.in. rozbudowy infrastruktury społecznej i technicznej, czy też rozwiązań transportowych. Istotnym elementem jest także ich integracja społeczna i asymilacja, zwłaszcza że ich potrzeby i oczekiwania zwykle nie odpowiadają ofercie usługowej nowego miejsca zamieszkania. Rokietnica jest przykładem gminy w aglomeracji poznańskiej, która w wyniku bardzo intensywnego napływu ludności, szybko straciła charakter wiejski - zarówno w aspekcie społecznym, jak i przestrzennym, czego przejawem są inwestycje deweloperskie realizowane na jej terenie. Podstawą efektywnego funkcjonowania tej gminy jest wyjście naprzeciw tym wyzwaniom - ich identyfikacja i świadomość przewidywanych zmian oraz szukanie sposobów na spełnienie aktualnych i przyszłych potrzeb mieszkańców. Niezbędne do sprostania wyzwaniom $\mathrm{w}$ środowisku tak dynamicznych zmian są kompetencje włodarzy (lokalnych menedżerów) świadomie wdrażających politykę opartą na współpracy z mieszkańcami, innymi samorządami i ekspertami. Władze lokalne gminy Rokietnica, których przedstawicielem jest wójt gminy, w sposób świadomy i kompetentny realizują zadania, mające na celu zapobieganie negatywnym skutkom suburbanizacji strefy podmiejskiej miasta Poznania.

\section{PRZYPISY}

1 Aglomeracja poznańska rozumiana jest, jako obszar miasta Poznania i 17 gmin powiatu poznańskiego.

\section{BIBLIOGRAFIA}

Chmielewski J.M., 2001, Teoria urbanistyki w projektowaniu i planowaniu miast, Oficyna Wydawnicza Politechniki Warszawskiej, Warszawa.

Kaczmarek T., Bul R., Kaczmarek U., Mikuła Ł., Walaszek M., 2014, Wielokryterialna delimitacja obszaru metropolitalnego Poznania, [w:] T. Kaczmarek, (red.), Delimitacja poznańskiego obszaru metropolitalnego, Biblioteka Aglomeracji Poznańskiej, 26, s. 95-102, Bogucki Wyd. Naukowe, Poznań.

Kaczmarek T., Bąkowska E., 2015, Prognoza demograficzna Gminy Rokietnica dla celów oświatowych na lata 2015-2030, Centrum Badań Metropolitalnych UAM, Poznań.

Kaczmarek T., Bąkowska E., 2016, Raport z konsultacji społecznych na temat kierunków zagospodarowania przestrzennego cen- 
trum miejscowości Rokietnica, Centrum Badań Metropolitalnych UAM, Poznań.

Kaczmarek U., 2014, Spójnoś́ społeczno-gospodarcza i poziom urbanizacji w obszarze funkcjonalnym Poznania, [w:] T. Kaczmarek (red.), Delimitacja poznańskiego obszaru metropolitalnego, „Biblioteka Aglomeracji Poznańskiej”, 26, s. 35-44, Bogucki Wyd. Naukowe, Poznań.

Kajdanek K., 2012, Suburbanizacja po polsku, Nomos, Kraków.

Lorens, P., 2005, Suburbanizacja w procesie rozwoju miasta postsocjalistycznego, [w:] P. Lorens (red.), Problem suburbanizacji, „Biblioteka Urbanisty”, 7, s. 33-44.

„Master plan dla Poznańskiej Kolei Metropolitalnej”, http://www. kolej.metropoliapoznan.pl; 13.07.2016.
Parysek J.J., Wojtasiewicz L., Gruchman B., 2010, Wyzwania $i$ kierunki rozwoju aglomeracji poznańskiej, „Biblioteka Aglomeracji Poznańskiej”, 4, Bogucki Wyd. Naukowe, Poznań.

Słodczyk J., 2003, Przestrzeń miasta i jej przeobrażenia, Uniwersytet Opolski, Opole.

„Strategia zintegrowanych inwestycji terytorialnych w Miejskim Obszarze Funkcjonalnym Poznania", Poznań 2015.

„Studium uwarunkowań i kierunków zagospodarowania przestrzennego gminy Rokietnica", Uchwała Rady Gminy Nr XVIII/181/ 2016 z 29 lutego 2016 r.

Artykuł wpłyną: 28 maja 2016 Zaakceptowano do druku: 18 września 2016 